\title{
PENGARUH KOMPETENSI, KOMITMEN ORGANISASI, DAN LOCUS OF CONTROL TERHADAP PRESTASI KERJA PEGAWAI PADA BADAN KEPEGAWAIAN DAN PENGEMBAGAN SUMBER DAYA MANUSIA KOTA SUNGAI PENUH
}

\author{
ADE YUSANTO, ELFISWANDI \\ ${ }^{1}$ Fakultas Ekonomi dan Bisnis Universitas Putra Indonesia "YPTK" Padang \\ e-mail : ade.yusanto83@gmail.com \\ ${ }^{2}$ Fakultas Ekonomi dan Bisnis Universitas Putra Indonesia "YPTK" Padang \\ e-mail : elfiswandi@upiyptk.ac.id
}

\begin{abstract}
This study aims to determine the effect of independent variables on the dependent variable. The object of this study is the employee of the Human Development Agency (BKPSDM) Sungai Sungai City. The number of samples in this study were 98 respondents. The analysis technique used is multiple linear regression. The research results obtained based on the partial test (t test) obtained: (a) There is a positive and significant effect of competence on work performance. (b) There is a positive and significant effect on commitment to work performance. c) There is a positive and significant influence of locus of control on work performance. The results of the study simultaneously showed that competence, commitment, locus of control had a positive and significant effect on work performance. And based on the coefficient of determination test (R2) the value is 0.541 or $54.1 \%$ this shows that the percentage of contribution of the independent variable competence, commitment, locus of control to the dependent variable work performance is 0.541 or $54.1 \%$. While the remaining $45.9 \%$ is influenced by other variables outside this study.
\end{abstract}

Keywords: Competence, Commitment, Locus of Control and Job Performance

\begin{abstract}
ABSTRAK
Penelitian ini bertujuan untuk mengetahui pengaruh variabel independen terhadap variabel dependen. Objek penelitian ini adalah pegawai Badan Kepegawaian Dan Pengembangan Sumber Daya Manusia (BKPSDM) Kota Sungai Penuh. Jumlah sampel dalam penelitian ini sebanyak 98 responden. Teknik analisis yang digunakan adalah regresi linear berganda. Hasil penelitian yang didapatkan berdasarkan Uji Parsial (Uji t) diperoleh: (a) Terdapat pengaruh positif dan signifikan kompetensi terhadap prestasi kerja. (b) Terdapat pengaruh positif dan signifikan komitmen terhadap prestasi kerja. c) Terdapat pengaruh positif dan signifikan locus of control terhadap prestasi kerja. Hasil penelitian secara simultan menunjukkan bahwa kompetensi, komitmen, locus of control berpengaruh positif dan signifikan terhadap prestasi kerja. Dan berdasarkan uji koefisien determinasi $\left(\mathrm{R}^{2}\right)$ nilainya 0,541 atau $54,1 \%$ hal ini menunjukkan bahwa persentase sumbangan variabel independen kompetensi, komitmen, locus of control terhadap variabel dependen prestasi kerja sebesar 0,541 atau 54,1\%. Sedangkan sisanya sebesar $45,9 \%$ dipengaruhi oleh variabel lain di luar penelitian ini.
\end{abstract}

Kata kunci : Kompetensi, Komitmen, Locus of Control dan Prestasi Kerja 


\section{PENDAHULUAN}

Di era globalisasi dan reformasi birokrasi ini banyak terjadi perubahan yang begitu cepat, baik dalam dunia ekonomi, politik, sosial, budaya maupun tata pemerintahan. Konsekuensi logis akibat pesatnya perubahan yang terjadi menyebabkan sumber daya manusia memegang peranan yang sangat penting dalam meningkatkan kinerja organisasi baik itu organisasi swasta ataupun organisasi pemaritah. Segala proses yang diperlukan dalam pencapaian tujuan organisasi tidak terlepas dari sumber daya manusia, biak dari pengambilan keputusan, hingga pada proses evaluasi yang semuanya tidak dapat dipisahkan dari unsur sumber daya manusia.

Demikian halnya organisasi/instansi pemerintah yang menekankan bahwa sumber daya manusia yang dalam hal ini pegawai berperan penting dalam memberikan pelayanan kepada masyarakat. Pegawai dtuntut bekerja lebih disiplin, profesional, dan beretika untuk mendukung reformasi birokrasi dan menunjang kelancaran tugas pemerintah dalam rangka memberikan pelayanan yang prima kepada masyarakat.

Dalam upaya meningkatkan sumber daya manusia di Kota Sungai Penuh prestasi kerja sangat penting. Nurheni (2016) prestasi kerja adalah hasil kerja yang dicapai oleh setiap pegawai pada suatu satuan organisasi sesuai dengan sasaran kerja pegawai dan perilaku kerja. Penilaian prestasi kerja Pegawai dilaksanakan secara sistematis yang penekanannya pada tingkat capaian sasaran kerja pegawai atau tingkat capaian hasil kerja yang telah disusun dan disepakati bersama antara Pegawai dengan pejabat penilai.

Menurut Heru, (2016) Prestasi kerja adalah suatu hasil kerja yang dicapai seseorang dalam melaksanakan tugas-tugas yang dibebankan kepadanya dan didasarkan atas kecakapan, pengalaman, dan kesungguhan serta waktu.Prestasi kerja merupakan gabungan dari 3 faktor penting, yaitu kemampuan dan penerimaan atas penjelasan delegasi tugas serta peran dan tingkat motivasi seseorang karyawan semakin tinggi angka untuk ketiga faktor ini semakin besar prestasi kerja karyawan yang bersangkutan.

Prestasi kerja dipengaruhi banyak faktor, salah satu di antaranya kompetensi. Menurut Wibowo (2012:324) kompetensi adalah suatu kemampuan untuk melaksanakan pekerjaan atau tugas yang dilandasi atas keterampilan dan pegetahuan serta dukungan oleh sikap kerja yang dituntut oleh pekerjaan tersebut.

Selanjutnya selain kompetensi komitmen juga sangat penting, untuk tercapainya prestasi kerja pegawai yang baik. Menurut Irfan, (2017) Adanya komitmen yang tinggi dari para karyawan terhadap masing-masing fungsi dan masa depan organisasi akan membawa dampak pada keuntungan organisasi secara umum dan juga pada pengalaman, serta perkembangan kemampuan dan prestasi masing masing karyawan itu sendiri. Menurut Windy, (2012) komitmen organisasional sebagai "derajat seberapa jauh karyawan mengidentifikasikan dirinya dengan organisasi dan keterlibatannya dalam organisasi tertentu

Selain kompetensi, komitmen, locus of contol juga sangat penting dalam meningkatkan prestasi kerja pegwai. Menurut Saputro, (2018) Internal locus of control adalah cara pandang bahwa segala hasil yang didapat baik atau buruk adalah karena tindakan kapasitas dan faktor - faktor dalam diri mereka sendiri. Internal locus of control adalah keyakinan seseorang bahwa di dalam dirinya tersimpan potensi besar untuk menentukan nasib sendiri, tidak peduli apakah lingkungannya akan mendukung atau tidak mendukung. Menurut Vindi, (2018) Locus of control merupakan salah satu faktor yang sangat menentukan perilaku individu dan juga locus of control didefenisikan sebagai gambaran pada kenyakinan seseorang mengenai sumber penentu perilakunya. 


\section{METODOLOGI PENELITIAN}

\subsection{Objek Penelitian}

Penelitian dilakukan pada Badan Kepegawaian dan Pengembangan Sumber Daya Manusia (BKPSDM) Kota Sungai Penuh, beberapa persiapan telah dilakukan sebelumnya. Pemilihan

Lokasi ini didasarkan pertimbangan karena peneliti adalah salah satu pegawai Badan Kepegawaian dan Pengembangan Sumber Daya Manusia (BKPSDM) Kota Sungai Penuh. Pada penelitian ini berfokus pada pengaruh kompetensi, komitmen, locus of control terhadap prestasi kerja.

\subsection{Variabel Operasional}

Pada penelitian ini penulis menggunakan dua variabel yaitu:

1. Variabel Bebas (independent)

Variabel ini sering di sebut variabel stimulus, predictoe dan antecedent. Dalam bahasa indonesia disebut sebagai variabel bebas. Variabel bebas merupakan variabel yang mempengaruhi atau yang menjadi sebab perubahannya atau timbulnya variabel dependen. Variabel independen yang dilambangkan dengan (X) adalah variabel yang mempengaruhi variabel dependen, baik yang pengaruhnya positif maupun yang pengaruhnya negatif. Variabel independen dalam penelitian ini adalah :
a. Kompetensi $\left(\mathrm{X}_{1}\right)$
b. Komitmen $\left(\mathrm{X}_{2}\right)$
c. Locus of Control $\left(\mathrm{X}_{3}\right)$

2. Variabel Terikat (Dependen)

Variabel terikat merupakan variabel yang mempengaruhi atau yang menjadi akibat, karena adanya variabel bebas. Variabel dependen adalah variabel yang menjadi pusat perhatian utama peneliti. Dalam penelitian ini yang menjadi variabel dependen adalah prestasi kerja (Y)

\subsection{Analisis Regresi Linier Berganda}

Alat analisis data yang digunakan dalam penelitian ini adalah analisis regresi berganda untuk membuktikan pengaruh kompetensi, komitmen, locus of control terhadap prestasi kerja pada Badan Kepegawaian dan Pengembangan Sumber Daya Manusia (BKPSDM) Kota Sungai Penuh.

Dengan demikian, dapat dikemukakan persamaan regresi linear berganda dalam penelitian ini adalah sebagai berikut :

$$
\mathbf{Y}=\mathbf{a}+\mathbf{b}_{1} \mathbf{X}_{1}+\mathbf{b}_{2} \mathbf{X}_{2}+\mathbf{b}_{3} \mathbf{X}_{3}+\mathbf{e}
$$

Keterangan :

$$
\begin{array}{ll}
\mathrm{Y} & =\text { Prestasi kerja } \\
\mathrm{a} & =\text { Konstanta } \\
\mathrm{b} & =\text { Koefisien regresi } \\
\mathrm{X}_{1} & =\text { Kompetensi } \\
\mathrm{X}_{2} & =\text { Komitmen } \\
\mathrm{X}_{3} & =\text { Locus of control } \\
\mathrm{e} & =\text { Error }
\end{array}
$$




\section{Uji Parsial (Uji-t)}

Uji t dilakukan untuk mengatahui tingkat signifikan pengaruh variabel bebas terhadap variabel terikat secara parsial. Dalam hal ini untuk menguji pengaruh kompetensi, komitmen, locus of control terhadap prestasi kerja.

\section{Uji Simultan (Uji-F)}

Uji statistik F digunakan untuk menguji seluruh variabel independen kompetensi, komitmen, locus of control yang diteliti mempunyai pengaruh secara bersama-sama terhadap variabel dependen prestasi kerja dilakukan dengan membandingkan F-hitung dengan F-tabel.

\section{Uji Koefisien Determinasi (R-Square/ $\mathbf{R}^{2}$ )}

Koefisien determinasi berganda $\left(\mathrm{R}^{2}\right)$ atau $\mathrm{R}$ squared berarti secara bersama-sama menyatakan besar kecilnya sumbangan variabel bebas terhadap variabel terikat. $\mathrm{R}$ squared berkisar pada angka 0 sampai 1, dengan catatan semakin kecil angka $\mathrm{R}$ squared, semakin lemah pula hubungan kedua atau lebih varibel tersebut.

\section{III.HASIL DAN PEMBAHASAN}

Kuesioner disebarkan kepada pegawai Badan Kepegawaian dan Pengembangan Sumber Daya Manusia Kota Sungai Penuh sebanyak 98 buah dan semua kuesioner berhasil dikumpulkan kembali.

\section{Uji Normalitas}

Sarjono (2011:53) menyatakan, uji normalitas bertujuan untuk mengetahui normal atau tidaknya suatu distribusi data. Pada dasarnya, uji normalitas adalah membandingkan antara data yang kita miliki dan data berdistribusi normal yang memiliki mean dan standar deviasi yang sama dengan data kita. data yang diuji lebih besar dari pada 50 (respondennya lebih dari 50 orang) menggunakan angka signifikansi uji kolmogorov-Smirnov. Jika data yang diuji lebih kecil dari pada 50, peneliti menggunakan sig Shapiro Wilk. Tingkat signifikan > 0,05 menunjukkan data berdistribusi normal. Hasil uji normalitas dapat dilihat pada gambar di bawah ini :

\section{Tabel 4.1 Uji Normalitas}

\begin{tabular}{llr}
\hline & & Unstandardized Residual \\
\hline $\mathrm{N}$ & & 98 \\
Normal Parameters & Mean &, 0000000 \\
& Std. Deviation & 5,03161412 \\
Most Extreme Differences & Absolute &, 068 \\
& Positive &, 047 \\
& Negative &,- 068 \\
Test Statistic & &, 673 \\
Asymp. Sig. (2-tailed) & &, 756 \\
\hline \multicolumn{2}{c}{ Sumber : Lampiran Print out SPSS }
\end{tabular}

Berdasarkan tabel di atas dapat diketahui bahwa nilai Asymp.Sig.(2-tailed) sebesar $0,756>0,05$. artinya data berdistribusi normal dan memenuhi uji asumsi klasik sehingga dapat dilanjutkan ke proses selanjutnya.

\section{Uji Multikolinearitas}

Penilaian multikolinieritas dilakukan dengan membandingkan nilai VIF, jika nilai ini > 5 atau 10 dan nilai tolerance mendekati 1 (satu) maka tidak terjadi multikoliniearitas. 
Namun jika sebaliknya, jika nilai VIF > 5 atau 10 dan nilai tolerance menjauhi 1 (satu) maka terjadi multikolinearitas. Hasil uji multikolinearitas dapat di lihat pada tabel berikut :

Tabel 4.2 Hasil Uji Multikolinearitas

\begin{tabular}{|c|c|c|}
\hline \multirow[b]{2}{*}{ Model } & \multicolumn{2}{|c|}{ Collinearity Statistics } \\
\hline & Tolerance & VIF \\
\hline \multicolumn{3}{|l|}{1 (Constant) } \\
\hline Kompetensi & ,670 & 1,493 \\
\hline Komitmen & ,684 & 1,462 \\
\hline Locus of Control & ,722 & 1,386 \\
\hline
\end{tabular}

Dari tabel di atas didapatkan hasil pada variabel kompetensi $\left(\mathrm{X}_{1}\right)$ nilai tolerance 0,670 mendekati 1 (satu) dan nilai VIF 1,493 lebih kecil dari 5 atau 10 maka dinyatakan data tidak terjadi multikoliniearitas. Variabel kompetensi $\left(\mathrm{X}_{2}\right)$ nilai tolerance 0,684 mendekati 1 (satu) dan nilai VIF 1,462 lebih kecil dari 5 atau 10 maka dinyatakan data tidak terjadi multikoliniearitas. Variabel locus of control $\left(\mathrm{X}_{3}\right)$ nilai tolerance 0,722 mendekati 1 (satu) dan nilai VIF 1,386 lebih kecil dari 5 atau 10 maka dinyatakan data tidak terjadi multikoliniearitas.

\section{Uji Heteroskedastisitas}

Penilaian Heteroskedastisitas dapat diperhatikan pada tabel coefficients dengan memperhatikan nilai signifikan yang dihasilkan. Jika nilai signifikan $>0,05$ maka tidak terjadi Heteroskedastisitas. Sebaliknya, jika nilai signifikannya < dari 0,05 maka terjadi heteroskedasititas. Hasil uji heteroskedasititas dapat dilihat pada gambar berikut :

\section{Gambar 4.3 Hasil Uji Heteroskedastisitas}

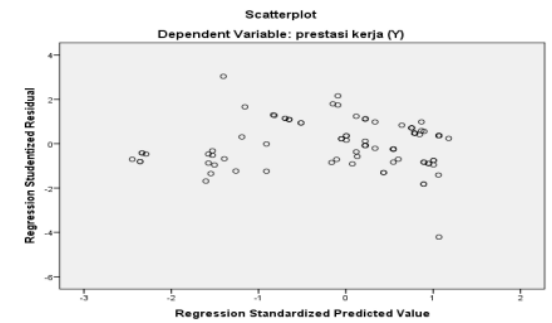

Sumber : Data diolah peneliti, 2020

Dari grafik diatas dapat diketahui bahwa tidak terjadi heteroskedastisitas pada model regresi sebab tidak ada pola yang jelas serta titik-titik menyebar diatas dan dibawah angka 0 pada sumbu Y. Sehingga dapat dikatakan uji heteroskedastisitas terpenuhi.

\section{Analisis Regresi Linier Berganda}

Untuk mengetahui pengaruh antara variabel pengaruh kompetensi, komitmen, locus of control terhadap prestasi kerja maka digunakan analisis regresi linier berganda, dimana variabel bebasnya adalah kompetensi $\left(\mathrm{X}_{1}\right)$, komitmen $\left(\mathrm{X}_{2}\right)$, locus of control $\left(\mathrm{X}_{3}\right)$ serta variabel terikatnya adalah prestasi kerja $(\mathrm{Y})$. berikut hasil uji regresi yang dilakukan. Berikut ini hasil pengolahan data didapatkan hasilnya terlihat pada tebel berikut :

Tabel 4.3 Hasil Regresi Linier Berganda

\begin{tabular}{llrrr|l}
\hline \multicolumn{5}{c}{ Unstandardized Coefficients } \\
& \multicolumn{1}{c}{ B } & Std. Error & \multicolumn{1}{c}{ t } & Sig. \\
\hline 1 (Constant) & 14,520 & 3,789 & 3,832 &, 000 \\
& Kompetensi & &, 255 &, 056 & $4,581,000$
\end{tabular}




\begin{tabular}{|c|c|c|}
\hline Komitmen & ,316 & 016, 2,456 129, \\
\hline Locus of Control & ,261 & ,065 4,048, \\
\hline
\end{tabular}

\section{Sumber : Data diolah peneliti, 2020}

Berdasarkan perhitungan diperoleh nilai koefisien regresi kompetensi $\left(\mathrm{X}_{1}\right)$ sebesar 0,255 , nilai koefisien regresi komitmen $\left(\mathrm{X}_{2}\right)$ sebesar 0,316 , nilai koefisien regresi locus of Control $\left(\mathrm{X}_{3}\right)$ sebesar 0,261 . Berdasarkan angka tersebut maka dapat disusun persamaan garis regresi sebagai berikut :

$$
Y=14,520+0,255 X_{1}+0,316 X_{2}+0,261 X_{3}+e
$$

\section{Uji Parsial (Uji-t)}

Uji t dimaksudkan untuk mengetahui seberapa besar pengaruh satu variabel independen (kompetensi, budaya organisasi, disiplin kerja) secara individual dalam menerangkan variabel dependen (kinerja pegawai). Berdasarkan tabel 4.3 diatas maka dapat ditarik kesimpulan bahwa :

1. Pengaruh Kompetensi Terhadap Prestasi Kerja

Dari tabel 4.3 terlihat t-hitung 4,581 dan t-tabel 1,661 dimana t-hitung lebih besar dari t-tabel $(4,581>1,661)$ atau tingkat signifikan lebih kecil dari alpha $(0,000<0,05)$ maka dapat diperoleh $\mathrm{H}_{0}$ ditolak $\mathrm{H}_{\mathrm{a}}$ diterima.

2. Pengaruh Komitmen Organisasi terhadap Prestasi Kerja

Dari tabel 4.3 terlihat t-hitung 2,456dan t-tabel 1,661 dimana t-hitung lebih besar dari t-tabel $(2,456>1,661)$ atau tingkat signifikan lebih kecil dari alpha $(0,016<0,05)$ maka dapat diperoleh $\mathrm{H}_{0}$ ditolak $\mathrm{H}_{\mathrm{a}}$ diterima.

3. Pengaruh Locus Of Control Terhadap Prestasi Kerja

Dari tabel 4.3 terlihat t-hitung 4,048 dan t-tabel 1,661 dimana t-hitung lebih besar dari t-tabel $(4,048>1,661)$ atau tingkat signifikan lebih kecil dari alpha $(0,000<0,05)$ maka dapat diperoleh $\mathrm{H}_{0}$ ditolak $\mathrm{H}_{\mathrm{a}}$ diterima.

\section{Uji Simultan (Uji-F)}

Untuk mendapatkan bukti empiris ada atau tidaknya pengaruh nyata antara variabel yang terdiri dari kompetensi, komitmen, locus of control secara bersama-sama terhadap prestasi kerja , maka dilakukan F-test. Berdasarkan hasil pengujian diperoleh ringkasan hasil seperti yang terlihat pada tabel di bawah ini :

\section{Tabel 4.4 Hasil Uji Simultan}

\begin{tabular}{lrrrrr}
\hline Model & Sum of Squares & df & Mean Square & F & Sig. \\
\hline 1 Regression & 3066,288 & 3 & 1022,096 & 39,123 &, $000^{\mathrm{b}}$ \\
Residual & 2455,763 & 94 & 26,125 & & \\
Total & 5522,051 & 97 & & & \\
\hline
\end{tabular}

\section{Sumber : Data diolah peneliti, 2020}

Dari tabel 4.4 diatas dapat dilihat pengujian ini dilakukan dengan cara membandingkan nilai $\mathrm{F}$ hitung dengan $\mathrm{F}$ tabel karena nilai $\mathrm{F}$ hitung lebih besar dari nilai $\mathrm{F}$ tabel $(39,123>2,70)$. Nilai F 6,804 dengan tingkat signifikan 0,000 lebih kecil dari 5\%. Maka diperoleh $\mathrm{H}_{0}$ ditolak dan $\mathrm{H}_{\mathrm{a}}$ diterima, yang berarti hal ini dilakukan secara bersama-sama 
antara kompetensi, komitmen organisasi dan locus of control berpengaruh signifikan terhadap prestasi kerja.

\section{Uji Koefisien Determinasi (R-Square)}

Analisis determinasi dalam regresi linier berganda digunakan untuk mengetahui persentase sumbangan pengaruh variabel independen terdiri dari kompetensi $\left(\mathrm{X}_{1}\right)$, komitmen $\left(\mathrm{X}_{2}\right)$, locus of Control $\left(\mathrm{X}_{3}\right)$ terhadap prestasi kerja $(\mathrm{Y})$. Hasil determinasi dapat dilihat pada tabel berikut :

\section{Tabel 4.5 Hasil Uji Koefisien Determinasi}

Model R R Square Adjusted R Square Std. Error of the Estimate

\begin{tabular}{lllll}
\hline 1 &, $745^{\mathrm{a}}$ &, 555 &, 541 & 5,11128 \\
\hline
\end{tabular}

Sumber : Data diolah peneliti, 2020

Dari tabel di atas diperoleh angka adjusted $\mathrm{R}$ square sebesar 0,541 hal ini menunjukkan bahwa sumbangan variabel kompetensi, komitmen, locus of control terhadap prestasi kerja 0,541 atau $54,1 \%$ sedangkan sisanya sebesar $45,9 \%$ dipengaruhi variabel lain di luar penelitian ini.

\section{Pembahasan}

Peningkatan kinerja merupakan hal yang diiginkan oleh semua orang, kinerja yang meningkat akan menghasilkan prestasi kerja. Prestasi kerja dapat diciptakan apabila seorang pegawai memiliki kompetensi, komitmen organisasi serta locus of control. Dari hasil penelitian diatas maka di dapatkan:

1) Pengaruh Kompetensi terhadap Prestasi Kerja

Dimana t-hitung 4,581 dan t-tabel 1,661 lebih besar dari t-tabel $(4,581>1,661)$ atau tingkat signifikan $(0,000<0,05)$. Hasil tersebut sesuai dengan dugaan peneliti terdahulu yang dilakukan oleh (Mei, 2019) dengan hasil yang menunjukkan bahwa kompetensi berpengaruh signifikan terhadap prestasi kerja.

2) Pengaruh Komitmen Organisasi terhadap Prestasi Kerja

Dimana t-hitung 2,456 dan t-tabel 1,661 lebih besar dari t-tabel $(2,456>1,661)$ atau tingkat signifikan $(0,016<0,05)$. Hasil tersebut sesuai dengan dugaan peneliti terdahulu yang dilakukan oleh (Ratrianti, 2016) dengan hasil yang menunjukkan bahwa komitmen berpengaruh signifikan terhadap prestasi kerja.

3) Pengaruh Locus Of Contol terhadap Prestasi Kerja

Dimana t-hitung 4,048 dan t-tabel 1,661 lebih besar dari t-tabel $(4,048>1,661)$ atau tingkat signifikan $(0,000<0,05)$. Hasil tersebut sesuai dengan dugaan peneliti terdahulu yang dilakukan oleh (Vindi,2018) dengan hasil menunjukkan bahwa locus of contol berpengaruh terhadap prestasi belajar

4) Pengaruh Kompetensi, Komitmen Organisasi, Locus Of Contol terhadap Prestasi Kerja.

Dimana F-hitung lebih besar dari F tabel $(39,123>2,70)$ Nilai F 6,804 dengan tingkat signifikan 0,000 lebih kecil dari 5\%. Sumbangan-sumbangan Kompetensi, Komitmen Organisasi, Locus $O f$

Control terhadap prestasi kerja sebesar 0,541 atau $54,1 \%$ sedangkan sisanya sebesar $45,9 \%$ dipengaruhi oleh variabel lain.

\section{KESIMPULAN}

Hasil penelitian ini menunjukkan bahwa kompetensi berpengaruh dan signifikan terhadap prestasi kerja, komitmen berpengaruh dan signifikan terhadap prestasi kerja, locus 
of control berpengaruh signifikan terhadap prestasi kerja, kompetensi, komitmen, locus of control secara bersama-sama berpengaruh dan signifikan terhadap prestasi kerja BKPSDM Kota Sungai Penuh.

\section{UCAPAN TERIMAKASIH}

Terima kasih kepada Universitas Putra Indonesia "YPTK" Padang yang telah memberikan kesempatan penulis untuk menyelesaiakan jurnal ini dan LPPM STIA Nusantara Sakti Sungai Penuh yang telah memberi kesempatan untuk publish jurnal di OJS Jurnal Administrasi Nusantara (JAN). Sertasemua pihak yang tidak bisa disebutkan satu persatu dalam jurnal ini.

\section{DAFTAR RUJUKAN}

Amstrong, Michael. 2011. Performance Management and Development, the edition, New York, McGraww Hill, Inc.

Achmad S. Ruky. 2015, Sistem Manajemen Kinerja, Jakarta : PT. Gramedia Pustaka utama.

Arikunto, Suharsimi. 2012. Prosedur Penelitian. Suatu Pendekatan Praktek.Jakarta: Rineka Cipta.

Budiharjo Andreas. 2014. Peranan budaya perusahaan : Suatu pendekatan Sistematik dalam mengelola perusahaan . Prasetya Mulya Management Jurnal Vol. VIII No.14

Bambang Juanda. 2011. Medologi Penelitian Ekonomi \& Bisnis, Penerbit IPB Press

Dharma, A. 2014. Managemen Prestasi Kerja. Jakarta : Rajawali Press

Gibson, James L. 2013. Organizations (Behavior, Structure, Processes. Twelfth Edition, McGrow Hill.

Ghozali, Imam. 2011. Aplikasi Analisis multivariat dengan Program SPSS. Semarang : Badan Penerbit Universitas Diponegoro

Handoko, T.H. 2016. Manajemen Personalia dan Sumber daya Manusia. Yogyakarta: BPFE Press.

http://kmpk.ugm.ac.id

Hasibuan, S. Melayu. 2016. Manajemen Sumber Daya Manusia. Jakartal : Bumi Aksara

Hernowo Narmodo dan M. Farid Wajdi. 2008. Pengaruh Motivasi dan Disiplin Terhadap Kinerja Pegawai Badan Kepegawaian Daerah Kabupaten Wonogiri

Hoiriya. 2018. Pengaruh Kompetensi dan Disiplin Kerja terhadap Kinerja Pegawai Pada Badan Kepegawaian dan Pengembangan Sumber Daya Manusia Daerah (BKPSDMD) Kabupaten Bangka. Jurnal Riset Manajemen dan Akuntansi Vol. 1 No.1 Ferbruari 2018

I Wayan Tresna Ariana \& I Gede Riana. 2012. Pengaruh Kepemimpinan, Kompensasi dan Disiplin Kerja Terhadap Kinerja Karyawan Pada Hotel Cendana Resort \& Spa Ubud, Gianyar. Jurnal.

J. Supranto dan Nandan Limakrisna. 2012. Petunjuk Praktis Penelitian Ilmiah Untuk Menyusun Skripsi, Tesis dan Disertasi. Jakarta : Penerbit Mitra Wacana Media

Kuncoro, Mudrajad. 2011. Metode Riset untuk Bisnis dan Ekonomi. Jakarta: Penerbit Erlangga.

Lako, Andreas. 2015. Kepemimpinan dan Kinerja Organisasi. Yogyakarta: Amara Books.

Mardi Astutik. 2016. Pengaruh Disiplin Kerja dan Budaya Organisasi terhadap Kinerja Pegawai Sekretariat Dewan Perwakilan Rakyat Daerah Kabupaten Jombang. Jurnal

Mathis, Robert L and Jackson, John H. 2011. Manajemen Sumber Daya Manusia, Edisi 10, terjemahan, Salemba Empat 
Mc Cormic, D.W, 2010, Spirituality and Management, Journal Of Managerial Psychology, Vol.9, pp.5-8

Masngudi, Prof. DR. H. 2012. Metologi Penelitian untuk Ekonomi \& Bisinis, Penerbit Trianandra University Press Jakarta

Nawawi, Hadari. 2014. Manajemen Sumberdaya Manusia, Gajahmada University Press, Yogyakarta

Nitisemito, Alex S. 2015. Manajemen Personalia. Jakarta : Ghalia Indonesia

Pandi Afandi \& Bambang Supeno. 2016. The Influence of Competence, Organization Culture and Work Environment to Teacher's Performance As Well As Its Implication on Grad Competence of State Senior Islam Schools on Padang City. International Journal of Business and Management; Vol. 11, No. 5; 2016 ISSN 1833-3850 E-ISSN 18338119.

PP no 53 tahun 1980 (1980)

Rachmawati, Eka Nursani. 2010. Budaya Organisasi : Akankah meningkatkan Kinerja karyawan. Jurnal Kiat Vo. IV No. 11

Ravianto. 2015. Production of Management, LSIUP. Jakarta

Ruky, Achmad S. 2015. Sistem Manajemen Kinerja. Jakarta: Gramedia Pustaka Utama

Robbins, Stephen P. 2012. Perilaku Organisasi Jilid I dan II, Alih bahasa: Hadyana Pujaatmaka dan Benyamin Molan, Prenhallindo, Jakarta

Rivai, Veithzal. dan Sagala, Ella J. 2013. Manajemen Sumber Daya Manusia untuk Perusahaan dari Teori ke Praktik, Edisi ke 2 Jakarta : PT. Raja Grafindo Persada.

Ria Prasetya Safitri. 2018. Pengaruh Budaya Perusahaan Terhadap Motivasi Kerja dan dampaknya Pada Kinerja Karyawan. Journal of management review ISSN-P : 25804138ISSN-E2579-812X Volume 2 Number 2 Page (198-202)

Sakaran, Umar. 2016. Research Method for Business. Salemba Empat. Jakarta.

Siagian, Sondang. P. 2014. Manajemen Sumber Daya Manusia. Jakarta: Bumi

Sugiyono. 2011. Metode Penelitian Adminisirasi, Bandung : Alfabeta.

Sudjana. 2012. Metoda Statistika, Bandung : Tarsito

Spencer. 2015. Competene at work, Jhon wiley, New York.

Sutrisno, H. Edy. 2011. Manajemen Sumber Daya Manusia. Jakarta: Kencana

Thoha, Miftah, 2012. Perilaku Organisasi - konsep dasar dan aplikasinya. Penerbit Rajawali. Jakarta.

Untung Sriwidodo dan Agus Budhi Haryanto 2010. Meneliti Pengaruh Kompetensi, Motivasi, Komunikasi Dan Kesejahteraan Terhadap Kinerja Pegawai Dinas Pendidikan.

Zamkosti. 2012. Analisis Kinerja Pegawai Berdasarkan Budaya organisasi, Lingkungan Kerja dan Disiplin Kerja Pada Kantor Kementerian Agama Propinsi Sumatera Barat. Jurnal.

Zainun, Buchari. 2007. Manajemen dan Motivasi, Edisi Revisi. Balai Aksara. Jakarta.

Zulhanif. 2014. Analisis Pengaruh Kompetensi, Budaya Organisasi Dan Motivasi Kerja Terhadap Kinerja Pegawai Pada Dinas Koperindag Dan UMKM Kabupaten Solo 